Brit. J. vener. Dis. (1957), 33, 120.

\title{
EVALUATION OF PRICE'S PRECIPITATION REACTION IN THE SERO-DIAGNOSIS OF SYPHILIS*
}

\author{
BY \\ M. R. DAREKAR AND H. I. JHALA \\ Pathology School, Grant Medical College, Bombay, India
}

The precipitation reaction for the diagnosis of syphilis (PPR) introduced by Price (1948) has been widely used in Great Britain, but few reports have so far been published evaluating the test as a diagnostic procedure (Singh and Sharma, 1951; Wilkinson, 1954; Evans, 1954; Macfarlane, Anderson, and Pinion, 1953; Mason and Headland, 1955). This paper examines the value of the PPR with regard to sensitivity and specificity, both alone and in combination with other reactions such as the Meinicke slide test (MST), the Kahn test, and the VDRL test. It also correlates the clinical status with serological reactivity.

\section{Materials and Methods}

(1) Meinicke Slide Test.- The modified method of Kvittingen (1948) was employed, using fresh sera and the antigen supplied by W.H.O.

(2) VDRL Slide Test.-Here the technique of the test as reported by Harris (1953) from the Venereal Disease Research Laboratory, Chamblee, Georgia, was used. The antigen was supplied by W.H.O.

(3) Kahn Standard Qualitative Test.-The method employed was that of Kahn (1950).

(4) Price's Precipitation Reaction.-The technique of Price (1948) was followed in its entirety except in the method of reporting. The quantitative results were expressed in terms of serum dilution instead of in units. The antigen was prepared in the laboratory from ox-heart as described by Price (1948).

Sera for Testing.-Sera of various categories for the evaluation of the PPR were personally obtained from the following sources:

(i) Blood samples from syphilitic subjects obtained from patients attending the Anti-Venereal Municipal Clinic and the V.D. Department of the J. J. Group of Hospitals. In each case a detailed history was available.

(ii) A number of blood samples from subjects with diseases other than syphilis obtained from patients in various wards of the J. J. Group of Hospitals.

\footnotetext{
* Received for publication April 12, 1957.
}

(iii) Leprosy sera obtained from the Acworth Leper Home, Wadala, Bombay.

(iv) A group of sera from normal non-syphilitic individuals selected from the staff of the Pathology School, Anti-Venereal Municipal Clinic, and from students.

Complete histories were taken in all cases with very careful questioning. Only cases that stood the scrutiny of history and physical findings were included.

Cerebrospinal Fluid for Testing.-These specimens were obtained from patients in the wards of the J. J. Group of Hospitals. They included fluids from carefully selected syphilitic and non-syphilitic patients.

Methods. - Blood samples were numbered and centrifuged to separate the serum and were first tested by the Meinicke slide test. Thereafter, the sera were heated at $56^{\circ} \mathrm{C}$. for 30 minutes, cooled to room temperature, and tested by the Kahn, VDRL, and PPR tests. If these tests could not be done on the same day, the sera were kept in the refrigerator at $0-5^{\circ} \mathrm{C}$. In order to prevent the reactivation of the complement, the sera were once again heated for 10 minutes at $56^{\circ} \mathrm{C}$. before testing them on the next day.

Pooled positive and negative sera were picked up from the previous tests and served as controls. The controls were kept in the refrigerator with $1: 10,000$ merthiolate as preservative.

In accordance with the recommendations of the National Serology Advisory Council of the U.S. Public Health Service (1953), the terms "Reactive", "Weakly Reactive", and "Non-reactive" were used for the terms "Positive", "Doubtful", and "Negative" in reporting the test results. These recommendations also conform with those suggested by the Sub-Committee on Serology and Laboratory Aspects of the World Health Organization (1951).

All positive VDRL and PPR sera were examined quantitatively. Only three tests, namely the Meinicke slide test, the VDRL tube test, and the PPR, were done on the cerebrospinal fluids received for examination.

The specificity of the tests was calculated by the formula of Chacko, Gaub, and Gopalan (1955):

$$
\frac{\text { Non-reactive }+0.5 \text { Weakly Reactive } \times 100}{\text { Total Sera Tested }}
$$


The calculation was made entirely from a series of known non-syphilitic sera and was expressed as a percentage.

The sensitivity of the tests was also calculated by the formula of Chacko and others (1955):

$$
\frac{\text { Reactive }+0.5 \text { Weakly Reactive } \times 100}{\text { Total Sera Tested }}
$$

The calculation in this case was made entirely from a series of known syphilitic sera and was expressed as a percentage.

The overall comparison of the Price Precipitation Reaction with the other three tests (Meinicke, VDRL, and $\mathrm{Kahn}$ ) was made in accordance with the recommendations of the Serology Sub-Committee of the W.H.O. (1954). Thus, the comparison is not based on the "percentage of agreement" of both the reactivity and the non-reactivity in both the tests, but on the percentage of agreement obtained from total reactivity in both tests. This makes the results all the more comparable, as negativity in both tests is no criterion of agreement. It is also stressed that in making such overall comparisons between any two tests, the series should not contain a high percentage either of negative reactors or of strong reactors. The series reported in this paper was selected with due consideration of these factors.

\section{Results}

The Price Precipitation Reaction was performed in parallel with the Meinicke slide test, the VDRL slide test, and the Kahn test on 2,031 specimens of serum. These included 1,326 sera from known cases of syphilis in various stages, 35 sera from apparently normal persons, and 670 sera from patients suffering from diseases other than syphilis.

The Price Precipitation Reaction, the Meinicke slide test, and the VDRL tube test were also performed on eighty specimens of cerebrospinal fluid, which included 59 specimens from patients in various stages of late syphilis (untreated) and 21 specimens from persons suffering from diseases other than syphilis.

Comparisons.-Table I gives the overall comparison between the PPR, MST, VDRL, and Kahn tests. It shows the maximum agreement between the PPR and Kahn tests, and the minimum between

TABLE I

SHOWING OVERALL COMPARISON IN TESTS OF 2,031 SERA

\begin{tabular}{c|c}
\hline Battery of Tests & Percentage of Agreement among Reactors \\
\hline PPR/MST & $84 \cdot 35$ \\
\hline PPR/VDRL & $83 \cdot 22$ \\
\hline PPR/Kahn & $88 \cdot 10$ \\
\hline
\end{tabular}

PPR and VDRL tests. The agreement of the MST with the PPR is of intermediate value.

Sensitivity in Sera.-Table II gives the overall sensitivity of the various tests. While the VDRL is the most sensitive test, the PPR has the lowest sensitivity. Of the remaining two tests, namely the MST and the Kahn test, which achieve an intermediate position, the sensitivity of the Kahn test is nearer to that of the PPR and hence lower than that of the MST which approximates to the VDRL.

TABLE II

SHOWING OVERALL SENSITIVITY OF MST, VDRL, KAHN, AND PPR IN TESTS OF 1,326 KNOWN SYPHILITIC SERA

\begin{tabular}{c|c|c}
\hline Test & $\begin{array}{c}\text { Author's Percentage of } \\
\text { Sensitivity }\end{array}$ & $\begin{array}{c}\text { Percentage Sensitivity of } \\
\text { Vogelsang and Haaland } \\
\text { (1951) }\end{array}$ \\
\hline MST & $66 \cdot 98$ & $65 \cdot 6$ \\
\hline VDRL & $70 \cdot 14$ & $62 \cdot 0$ \\
\hline Kahn & $63 \cdot 17$ & - \\
\hline PPR & $61 \cdot 15$ & - \\
\hline
\end{tabular}

Table III gives the percentage sensitivities of the tests in various stages of untreated syphilis.

TABLE III

SHOWING PERCENTAGE OF SENSITIVITY IN VARIOUS CATEGORIES OF UNTREATED SYPHILIS IN MST, VDRL,

\begin{tabular}{|c|c|c|c|c|c|}
\hline \multirow{2}{*}{$\begin{array}{l}\text { Total } \\
\text { Sera } \\
\text { Tested }\end{array}$} & \multirow{2}{*}{ Stages of Syphilis } & \multicolumn{4}{|c|}{ Percentage of Sensitivity } \\
\hline & & MST & VDRL & Kahn & PPR \\
\hline 737 & $\begin{array}{l}\text { Clinical Primary Syphilis } \\
\text { (dark-ground negative) }\end{array}$ & $64 \cdot 21$ & $68 \cdot 78$ & $63 \cdot 21$ & $60 \cdot 65$ \\
\hline 265 & $\begin{array}{l}\text { Primary Syphilis } \\
\text { (dark-ground positive) }\end{array}$ & $50 \cdot 56$ & $55 \cdot 84$ & $42 \cdot 26$ & $41 \cdot 13$ \\
\hline 145 & Secondary Syphilis & $93 \cdot 11$ & $95 \cdot 11$ & $92 \cdot 34$ & $92 \cdot 34$ \\
\hline 46 & Late Benign Syphilis .. & $91 \cdot 08$ & $97 \cdot 81$ & $91 \cdot 08$ & $89 \cdot 10$ \\
\hline 8 & Cardiovascular Syphilis & $100 \cdot 00$ & $87 \cdot 54$ & $75 \cdot 00$ & $87 \cdot 00$ \\
\hline 47 & $\begin{array}{l}\text { Syphilis of Central Ner- } \\
\text { vous System } \ldots\end{array}$ & $97 \cdot 83$ & $97 \cdot 83$ & $91 \cdot 12$ & $91 \cdot 12$ \\
\hline 14 & Congenital Syphilis & $92 \cdot 14$ & $82 \cdot 14$ & $92 \cdot 14$ & $92 \cdot 14$ \\
\hline 1,262 & All stages & $68 \cdot 29$ & $72 \cdot 20$ & $64 \cdot 78$ & $62 \cdot 46$ \\
\hline
\end{tabular}
KAHN, AND PPR TESTS OF 1,262 SERA

The pattern of the overall sensitivity rates (Table II) is in general agreement for the various stages of untreated syphilis (Table III), except in two instances: in sera from cases of cardiovascular and congenital syphilis, the MST excels the VDRL test in sensitivity. However, the number of these sera is too small to justify a definite conclusion being drawn. The PPR is the least sensitive in all stages of untreated disease, with the Kahn test coming next to it. 
TABLE IV

SHOWING PERCENTAGE OF SENSITIVITY IN VARIOUS CATEGORIES OF TREATED SYPHILIS IN MST, VDRL, KAHN, AND PPR TESTS OF 74 SERA

\begin{tabular}{|c|c|c|c|c|c|c|}
\hline \multirow{2}{*}{$\begin{array}{c}\text { Total } \\
\text { Sera } \\
\text { Tested }\end{array}$} & \multirow{2}{*}{\multicolumn{2}{|c|}{ Stages of Syphilis }} & \multicolumn{4}{|c|}{ Percentage of Sensitivity } \\
\hline & & & MST & VDRL & Kahn & PPR \\
\hline 38 & Primary Syphilis & .. & $50 \cdot 00$ & $63 \cdot 41$ & 36.84 & 28.94 \\
\hline 18 & Secondary Syphilis & .. & $50 \cdot 00$ & $77 \cdot 78$ & $44 \cdot 44$ & $38 \cdot 90$ \\
\hline 18 & Late Benign Syphilis & .. & $66 \cdot 71$ & $88 \cdot 92$ & $61 \cdot 11$ & $38 \cdot 91$ \\
\hline 74 & - & & $54 \cdot 18$ & $71 \cdot 62$ & $44 \cdot 59$ & $36 \cdot 49$ \\
\hline
\end{tabular}

TABLE V

OVERALL SPECIFICITY OF MST, VDRL, KAHN, AND PPR IN 705 NON-SYPHILITIC SERA

\begin{tabular}{l|c|c|c|c}
\hline \multirow{2}{*}{ Test } & \multirow{2}{*}{$\begin{array}{c}\text { Percentage of } \\
\text { Specificity }\end{array}$} & $\begin{array}{c}\text { Price } \\
(1949)\end{array}$ & $\begin{array}{c}\text { Saxena } \\
(1956)\end{array}$ & $\begin{array}{c}\text { Vogelsang and } \\
\text { Haaland (1951) }\end{array}$ \\
\hline MST & $93 \cdot 33$ & - & - & 98.95 \\
\hline VDRL & 90.35 & 93.80 & 96.68 & $99 \cdot 25$ \\
\hline Kahn & 94.04 & - & - & - \\
\hline PPR & 98.56 & 99.43 & $99 \cdot 68$ & - \\
\hline
\end{tabular}

TABLE VI

INCIDENCE OF NON-TREPONEMAL REACTIONS IN VARIOUS NON-SYPHILITIC CONDITIONS SHOWING SPECIFICITY OF VARIOUS TESTS

\begin{tabular}{|c|c|c|c|c|c|c|c|c|c|c|c|c|c|c|c|}
\hline \multirow{2}{*}{$\begin{array}{l}\text { Test } \\
\text { Result }\end{array}$} & & & & \multicolumn{3}{|c|}{ MST } & \multicolumn{3}{|c|}{ VDRL } & \multicolumn{3}{|c|}{ Kahn } & \multicolumn{3}{|c|}{ PPR } \\
\hline & & & & $\begin{array}{c}\text { Re- } \\
\text { active }\end{array}$ & $\begin{array}{c}\text { Weakly } \\
\text { Re- } \\
\text { active }\end{array}$ & $\begin{array}{l}\text { Non- } \\
\text { Re- } \\
\text { active }\end{array}$ & $\begin{array}{c}\mathbf{R e}- \\
\text { active }\end{array}$ & $\begin{array}{c}\text { Weakly } \\
\text { Re- } \\
\text { active }\end{array}$ & $\begin{array}{c}\text { Non- } \\
\text { Re- } \\
\text { active }\end{array}$ & $\begin{array}{c}\text { Re- } \\
\text { active }\end{array}$ & $\begin{array}{c}\text { Weakly } \\
\text { Re- } \\
\text { active }\end{array}$ & $\begin{array}{l}\text { Non- } \\
\text { Re- } \\
\text { active }\end{array}$ & $\begin{array}{c}\text { Re- } \\
\text { active }\end{array}$ & $\begin{array}{c}\text { Weakly } \\
\text { Re- } \\
\text { active }\end{array}$ & $\begin{array}{l}\text { Non- } \\
\text { Re- } \\
\text { active }\end{array}$ \\
\hline \multirow{12}{*}{$\begin{array}{l}\text { Con- } \\
\text { dition }\end{array}$} & Leprosy & $\ldots$ & 184 & 11 & 4 & 169 & 20 & 4 & 160 & 11 & 9 & 164. & 5 & 1 & 178 \\
\hline & Typhoid & $\cdots$ & 18 & - & - & 18 & - & - & 18 & - & - & 18 & - & - & 18 \\
\hline & Pneumonia .. & $\ldots$ & 8 & - & 1 & 7 & 2 & - & 6 & - & 2 & 6 & - & 一 & 8 \\
\hline & Bronchitis & $\ldots$ & 6 & - & 1 & 5 & 1 & - & 5 & - & - & 6 & 一 & - & 6 \\
\hline & Tuberculosis. . & $\ldots$ & 97 & 3 & 5 & 89 & 14 & - & 83 & 3 & 5 & 89 & 2 & - & 95 \\
\hline & Pregnancy & $\ldots$ & 334 & 21 & 6 & 307 & 23 & 4 & 307 & 7 & 22 & 305 & 2 & - & 332 \\
\hline & \multicolumn{2}{|c|}{ Infectious Hepatitis.. } & 6 & - & 1 & 5 & 1 & - & 5 & - & 1 & 5 & - & - & 6 \\
\hline & \multicolumn{2}{|c|}{ Rheumatoid Arthritis } & 6 & 1 & - & 5 & 1 & - & 5 & - & 1 & 5 & - & - & 6 \\
\hline & \multicolumn{2}{|c|}{ Cirrhosis of Liver .. } & 9 & - & - & 9 & - & - & 9 & 一 & - & 9 & - & - & 9 \\
\hline & \multicolumn{2}{|c|}{ Granuloma Inguinale } & 1 & 1 & - & - & 1 & - & - & - & 1 & - & - & - & 1 \\
\hline & \multicolumn{2}{|c|}{ Gonococcal Urethritis } & 1 & 1 & - & - & 1 & - & - & - & - & 1 & - & - & 1 \\
\hline & Normal & $\cdots$ & 35 & - & - & 35 & - & - & 35 & - & - & 35 & - & - & 35 \\
\hline Total & $\ldots \quad \ldots$ & $\ldots$ & 705 & 38 & 18 & 649 & 64 & 8 & 633 & 21 & 41 & 643 & 9 & 1 & 695 \\
\hline
\end{tabular}

Table IV gives the sensitivity percentages of the tests in various stages of treated syphilis; the pattern of overall sensitivity agrees closely with that shown in Table II.

Specificity in Sera.-Table V gives the percentage of overall specificity of the various tests and shows that the PPR is the most specific test and the VDRL the least specific; the Kahn test is next below the PPR, and the MST is just above the VDRL.

Table VI gives the incidence of non-treponemal reactions encountered with each of these tests in normal subjects and in patients with various nonsyphilitic diseases; it indicates the reactivity of various groups of non-syphilitic normal and diseased persons included in the investigation, and helps to amplify the information given in Table V.
Sensitivity in Cerebrospinal Fluid.-Table VII gives the percentages of sensitivity for the three tests of cerebrospinal fluid in patients with untreated late syphilis.

The PPR appears to be the least sensitive test. The VDRL test is seen to be intermediate in sensitivity, and the first place is held by the MST.

\section{TABLE VII}

PERCENTAGE OF SENSITIVITY OF MST, VDRL, AND PPR IN TESTS OF CEREBRO-SPINAL FLUID IN VARIOUS CATEGORIES OF UNTREATED LATE SYPHILIS

\begin{tabular}{c|c|c|c}
\hline \multirow{2}{*}{$\begin{array}{c}\text { Total } \\
\text { Cerebrospinal } \\
\text { Fluids Tested }\end{array}$} & \multicolumn{3}{|c|}{ Percentage of Sensitivity } \\
\cline { 2 - 3 } & MST & VDRL & PPR \\
\hline 59 & 64.4 & $57 \cdot 6$ & $52 \cdot 4$ \\
\hline
\end{tabular}


Specificity in Cerebrospinal Fluid.-Table VIII gives the percentages of specificity for the three tests of cerebrospinal fluid in patients with known non-syphilitic conditions.

\section{TABLE VIII}

INCIDENCE OF NON-TREPONEMAL REACTIONS IN CEREBROSPINAL FLUID IN VARIOUS NON-SYPHILITIC CONDITIONS

\begin{tabular}{l|c|c|c|c|c}
\hline Test & $\begin{array}{c}\text { No. of } \\
\text { Cerebro- } \\
\text { spinal } \\
\text { Fluids } \\
\text { Tested }\end{array}$ & Reactive & $\begin{array}{c}\text { Weakly } \\
\text { Reactive }\end{array}$ & $\begin{array}{c}\text { Non- } \\
\text { Reactive }\end{array}$ & $\begin{array}{c}\text { Percentage } \\
\text { of } \\
\text { Specificity }\end{array}$ \\
\hline MST & 21 & - & 2 & 19 & $95 \cdot 27$ \\
\hline VDRL & 21 & - & - & 21 & $100 \cdot 00$ \\
\hline PPR & 21 & - & - & 21 & $100 \cdot 00$ \\
\hline
\end{tabular}

The PPR and VDRL give equally specific results with CSF, though this is not the case with tests of serum. The Meinicke test is inferior in specificity to both of them.

The reactivity of the cerebrospinal fluid is also shown in Table VIII.

\section{Discussion}

In general, the PPR was found to be the most specific and the least sensitive test of the four studied in this work, for treated and untreated syphilis, for serum and cerebrospinal fluid, and for early and late manifestations of syphilis. The only other test which comes nearer in the evaluation of sensitivity and specificity is the Kahn test when used for serum in any stage of the disease, whether treated or untreated. This is also borne out in the overall comparison of the PPR with the Kahn and other tests.

The figures of overall sensitivity and specificity for the MST and the VDRL are available in the studies reported by Vogelsang and Haaland (1951), but very few reports are available for the PPR.

The overall specificity rate of 98.56 per cent. reported in this work is in close agreement with that of Price (1954), who reported it to be 99.43 per cent., and with that of Saxena (1956) who reported it to be 99.68 per cent. Both these authors also report a much lower rate of specificity for the VDRL test: the rate given by Price is 93.80 per cent. while Saxena gives 96.68 per cent. Saxena's series comprised 4,497 sera, while Price tested a series of 3,097 routine sera and 1,896 problem sera which had given indeterminate reactions in several tests. In comparing his two groups, Price found identical specificity rates; he was comparing the specificity rates of the PPR with the newer cardiolipin antigen used in the VDRL test. From the results reported above, it is possible to agree that the liability to obtain non-treponemal reactions is greater with the cardiolipin-type antigen than with the ordinary unpurified alcoholic extract of ox-heart (as used in the preparation of Price's antigen).

In the present series, the non-treponemal reactions were seven times more with VDRL than with PPR.

Saxena confirmed each of his non-treponemal reactions by the use of the TPI test, but no such confirmation was possible in this series.

In recent years, there has been a tendency to increase the sensitivity of the test for syphilis without due regard to specificity. Kahn (1950) stated that lowering the sensitivity levels of serological tests may prove to be a step in the right direction. While we have in cardiolipin antigen a more standardized antigen, there is a greater liability to non-treponemal reactions. A quantitative test has therefore to be done, and, unless a VDRL is repeatedly positive in high dilution or is seen to be rising in titre, the value of a positive VDRL test could still be questioned in the absence of a positive TPI test, or for that matter in the absence of signs, symptoms, and history of infection. The introduction of this refined antigen has thus increased the difficulty of assessing problem sera.

There is no single test so far available which would give an ideal of 100 per cent. sensitivity and 100 per cent. specificity; nor will any serological test distinguish completely between syphilis and the other treponematoses.

One has therefore to strike a balance between specificity and sensitivity. It would appear that this can be done only by using a battery of very sensitive and very specific tests, or by quantitative serology. From the present work, it seems justified to recommend Price's Precipitation Reaction as a component in a battery of tests in view of its greater specificity. Only the Kahn test approaches it in specificity. Such specific tests ought to be combined with more sensitive tests like the MST or VDRL. Quantitative serology could be done with PPR and VDRL with great advantage. It appears that reversion to negativity occurs much better with the PPR test in cases of treated syphilis. With the use of more sensitive tests it is likely that more cases of syphilis will receive treatment for the scars left by healed syphilis than for active syphilis.

Hitherto, the sensitivity of the PPR has not been evaluated separately for treated and untreated cases and for various stages of the disease. Neither have there been reports of separate evaluation for serum and cerebrospinal fluid. The few previous reports comparing the PPR with other tests are given in 
Table IX. The latter is based on "percentage of agreement", which is not such a good indication as the "percentage of agreement amongst reactors", a term which came into use after 1954, after most of the work reported in the Table was published. In order to make our figures comparable, we have presented them in this Table on the basis of "percentage of agreement". No major variations are seen in the figures reported by various workers except in those of Purandare (1950), who reports a very low rate of comparable results between the PPR and the Kahn test. Singh and Sharma (1951) place the sensitivity of the PPR closer to that of the MST than to that of the VDRL, but we consider that our series shows that the PPR approximates more closely to the MST than to the VDRL, in much the same way as does Mungale (1957). However, the contrast between the results of Singh and Sharma (1951) on the one hand and the results of the present series and that of Mungale on the other may be attributed to the inferior method of comparison based on terms of "percentage of agreement". Table I shows that a better comparative assessment may be based on terms of "percentage

TABLE IX

" PERCENTAGE OF AGREEMENT" BETWEEN VARIOUS PAIRS OF SEROLOGIC TESTS OBTAINED BY DIFFERENT

\begin{tabular}{|c|c|c|c|c|c|c|c|}
\hline \multirow{2}{*}{\multicolumn{3}{|c|}{ Author }} & \multirow{2}{*}{ Date } & \multicolumn{4}{|c|}{ Pairs of Tests } \\
\hline & & & & $\begin{array}{l}\text { PPR/ } \\
\text { MST }\end{array}$ & $\begin{array}{c}\text { PPR/ } \\
\text { VDRL }\end{array}$ & $\begin{array}{l}\text { PPR/ } \\
\text { Kahn }\end{array}$ & $\begin{array}{c}\text { PPR/ } \\
\text { WR }\end{array}$ \\
\hline Price & . & $\ldots$ & 1949 & - & - & $95 \cdot 90$ & $97 \cdot 3$ \\
\hline Purandare & . & . & 1950 & - & - & $78 \cdot 85$ & - \\
\hline \multicolumn{3}{|c|}{ Singh and Sharma.. } & 1951 & $93 \cdot 47$ & $93 \cdot 85$ & - & - \\
\hline Evans & . & .. & 1954 & - & - & $94 \cdot 04$ & - \\
\hline \multicolumn{3}{|c|}{ Headland and Mason } & 1955 & 一 & - & $98 \cdot 00$ & $98 \cdot 06$ \\
\hline Saxena & $\ldots$ & .. & 1956 & 一 & $90 \cdot 25$ & - & - \\
\hline Shah & .. & .. & 1956 & - & - & $93 \cdot 28$ & - \\
\hline Mungale & . & . & 1957 & $94 \cdot 30$ & $93 \cdot 20$ & - & - \\
\hline \multicolumn{3}{|c|}{ Darekar and Jhala } & 1957 & $92 \cdot 36$ & $91 \cdot 37$ & $94 \cdot 33$ & - \\
\hline
\end{tabular}

of agreement among reactors", and we would hold to the view that the PPR compares better with the MST than with the VDRL.

Lastly, one cannot ignore the fact that it is equally simple to prepare the antigen for the PPR and for the Meinicke test.

\section{Summary}

A serological evaluation of specificity, sensitivity, and overall comparability of various tests in relation to PPR using sera and cerebrospinal fluids from different groups of cases of known syphilis and known non-syphilitic conditions is given, using the current standardized criterion.

Thanks are due to Dr. (Mrs.) S. K. Sanzgiri, Medical Officer, Anti-Venereal Municipal Clinic, and to Dr. S. G. Tambe, Deputy Medical Officer, for their assistance and keen interest in this study, to the Honorary V.D. Specialist in the J. J. Group of Hospitals, and to the other honorary staff of the hospitals for their help, and to the staff of the Pathology School and post-graduate students for their cooperation.

\section{REFERENCES}

Chacko, C. W., Gaub, W. H., and Gopalan, K. N. (1955). Indian J. vener. Dis., 21, 1 .

Evans, A. J. (1954). British Journal of Venereal Diseases, 30, 212.

Harris, A. (1953). Bull. nat. Ass. clin. Lab., 5, 6.

Kahn, R. L. (1950). "Serology with Lipid Antigen", pp. 190, 243. Williams and Wilkins, Baltimore

Kvittingen, J. (1948). Acta path. microbiol. scand., 25, 767.

Macfarlane, L. R. S., Anderson, C. K., and Pinion, F. C. (1953). British Journal of Venereal Diseases, 29, 236.

Mason, J. K., and Headland, C. (1955). Ibid., 31, 254.

Mungale, M. D. (1957). Personal Communication.

Price, I. N. Orpwood (1948). J. clin. Path., 1, 91.

- (1949). British Journal of Venereal Diseases, 25, 67.

- (1954). Ibid., 30, 210.

Purandare, N. M. (1950). Minutes of the 91 st Meeting of the Teaching Pathologists, Bombay, Dec. 23, 1950.

Saxena, B. P. (1956). Personal Communication.

Shah, H. H. (1956). Personal Communication.

Singh, B., and Sharma, M. D. (1951). British Journal of Venereal Diseases, 27, 190.

U.S. Public Health Service (1953). Report of the National Serology Advisory Council to the Surgeon General.

Vogelsang, T. M., and Haaland, R. (1951). British Journal of Venereal Diseases, $27,52$.

Wilkinson, A. E. (1954). Ibid., 30, 38.

World Health Organization (1951). "Sub-Committee on Serology and Laboratory Aspects: Expert Committee on Venereal Infections and Treponematoses." W.H.O. techn. Rep. Ser., No. 33, p. 22. 